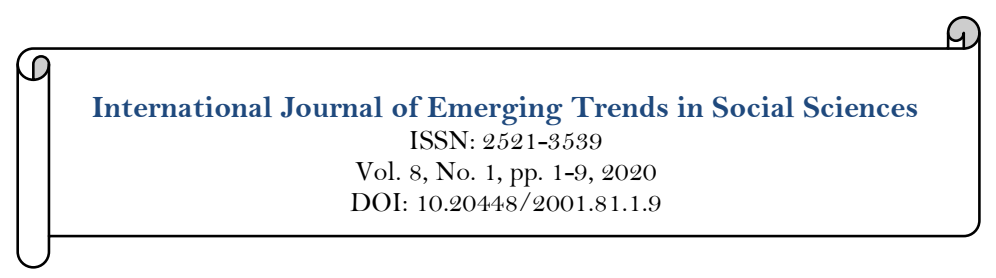

\title{
The Effect of Job Characteristics towards the Organizational Commitment of the Employees
}

\author{
Yanto Ramli ${ }^{*}$ \\ Mochamad Soelton ${ }^{2}$ \\ Paijan $^{3}$ \\ Nurul Khotimah ${ }^{4}$ \\ ${ }_{1,2,3,4}$ Universitas Mercu Buana, Indonesia \\ Email:yanto.ramli@mercubuana.ac.id
}

\begin{tabular}{|c|c|}
\hline Abstract & \\
\hline $\begin{array}{l}\text { Organization today are facing both the development of the fourth industrial } \\
\text { revolution, also known as Industry } 4.0 \text { and also the implication of millennial } \\
\text { workforce. The objective of this research is to analyze and develop the human } \\
\text { resource management in the organization in order to find out the } \\
\text { engagement of the millennial workforce commitment to the organization } \\
\text { and to find out the impact of the employee turnover intention within the } \\
\text { organization. The research in done through the distribution of } \\
\text { questionnaire, and the population of this research is consisted of the employees } \\
\text { in a local IT provider company in Jakarta, Indonesia. This research is } \\
\text { performed by using descriptive and verification method, the descriptive } \\
\text { method is based on observation analysis and the verification method is based } \\
\text { on quantitative analysis. The sample determination was done through Non- } \\
\text { Probability (Random Sampling) and the tool of analysis is using Partial } \\
\text { Least Square (PLS). The population of this research is based on 35o } \\
\text { employees of an IT provider company in Jakarta, Indonesia. The result } \\
\text { indicated that job characteristics have higher significant influence on } \\
\text { organizational commitment compared to career development that effect the } \\
\text { turnover intention of employees. Organizational commitment has a } \\
\text { significant effect on employee turnover intention. This means that in order to } \\
\text { counter the turnover intention of the millennial employees, the organization } \\
\text { must develop proper job characteristics to suit the millennial workforce which } \\
\text { might be useful to help overcome the research phenomenon. }\end{array}$ & $\begin{array}{l}\text { Keywords: } \\
\text { Job characteristics } \\
\text { Career development } \\
\text { Organizational commitment } \\
\text { Turnover intention. } \\
\text { Licensed: } \\
\text { This work is licensed under a } \\
\text { Creative Commons Attribution } 4.0 \\
\text { License. } \\
\text { Publisher: } \\
\text { Scientific Publishing Institute }\end{array}$ \\
\hline
\end{tabular}

Funding: This study received no specific financial support.

Competing Interests: The authors declare that they have no competing interests.

\section{Introduction}

Indonesia today are facing dramatically changes of the demographic and generations from the $\mathrm{X}$ generations to the $\mathrm{Y} /$ millennial generations, this generation has huge differences of both characteristic and behavior and also the development of the fourth industrial revolution known as Industry 4.0. The government of Indonesia has been suggesting that both the business and institutions sectors to coordinate in order to improve the quality standard of Indonesia's human resources management. The demographic changes of generations and the development of industrial revolution may have a major implication to the current workforce as the millennial generation is going to take over the management position and certain strategic positions in the organization (Ramli \& Soelton, 2019).

According to Lussier and Hendon (2016) human resource (HR) issues are emerging as some of the most prominent concerns for business owners and managers. Human resource managers needed to be more 
strategic, business focused, customer focused, and generally more in tune with the overall operational success of the organization. So, what is happening in today's business environment that might impact the human resource managers to think over their way of doing business? As a result, human resource managers as well as operational managers have been forced to include strategic terms about how their organization can win against competitors by utilizing their current human resources.

One of the primary means of creating a competitive advantage for the organization-is the people within an organization-because management of human resources affects company performance. This is because most organizations of comparable size and scope within the same industry generally have access to the same material and facilities-based resources that any other organization within the industry may have. This being the case, it is very difficult to create a competitive advantage based on material, facility, or other tangible or economic resources. What this frequently leaves are the people as the organization's most valuable asset. If the organization can manage its human resources more successfully than its competitors do, if it can get its employees involved in working toward the day-to-day success of the organization, and if it can get them to stay with the organization, then it has a much greater chance of being successful. Managers are responsible for getting the job done through employees, so the organization's human resources are nearly always its most valuable resource. If we can get our employees fully engaged, we can make better decisions, increase employee trust and loyalty, and improve productivity (Noe, Hollenbeck, Gerhart, \& Wright, 2017).

The former workplace in which managers simply told employees what to do is gone. You will most likely work in a team and share in decision making and other management tasks. Today, people want to be involved in management, and organizations expect employees to work in teams and participate in managing the firm. Modern organizations also expect significantly greater productivity than occurred in their historical counterparts. Today's HR managers are working along with all other managers within the organization to improve organizational revenue and profits. The managers of all department must do things to improve the productivity of the people who work for the organization to create productivity centers (Harzing \& Pennington, 2015).

Entering the industrial revolution era of 4.0 has become an important issue for Indonesia in order to spur the competence of human resources. In order to encounter the industry 4.0 revolution, the government of Indonesia has urged the private sectors as well as the educational sectors to improve the quality of HR in the coming stage to be well prepared and organized. The government has been preparing certain priority stages of strategies to implement the roadmap of making Indonesia 4.0. One of the priority stages is preparing the HR to accelerate the development of HR quality to compete with the global competition among the digital era of global competition (Ministry of Industry, Creative Industries Movement event, 2019).

\subsection{Human Resource Challenges}

According to Noe et al. (2017) human resource managers today are concerned with issues not only from the organization but also the current generation of employees. A recent survey done by the HR professionals about what challenges they think will be most significant over the next 10 years.

The three biggest challenges:

1. Retaining and rewarding the best employees.

2. Developing the next generation of corporate leaders.

3. Creating a corporate culture that attracts the best employees.

By reviewing these challenges is reasonably good at identifying and meeting some of them, while others have gone without significant attention to date in most companies. After years of observations, many companies have pursued better selection and retention strategies for a number of years, and have recently become much better to identify future leaders and managing organizational relationships, culture, and structure.

\subsection{Research Gap}

Based on several discussion of the previous research, Gadi and Hung (2018) that in order to reduce the level of employee turnover is to improve the job satisfaction by improving the skills of employees, inspire them to use the abilities and encourage them in work. Emiroglu, Akova, and Tanriverdi (2015) explained the demographic factors such as age, gender, marital status, education, as well as the factors such as tenure, wage, position, working department are determinants for turnover intention. Nasurdin, Ling, and Khan (2018) indicate that company should prepare for high performance work practices considering performance appraisal, compensation and employment security to reduce turnover over intention. Long and Perumal (2014) conclude that according to the empirical investigation in their study, performance management seem to have the strongest impact on turnover intention. Zahra, Khan, Aman, and Ali (2018) expressed that policy makers should take necessary measures to increase the supervisory support at work, minimize the work load and work ambiguity, and improve other job factors to decrease the employees' intention to leave the organization. According to Ramli and Soelton (2019) that the organization today are facing the challenges of somewhat less commitment and contribution of the millennial generation compare to the baby boomer or X generation. They tend to be easily bored and leave the company in order to seek for a better and higher pay and better 
environment. These might cause higher turnover of employees in the company. All the above researches are discussing about the phenomenon of employee turnover intention, while this research seeks to find out the problems encountered and provide solutions in overcoming the issues and recommending solutions to solve the issues based on the constructed variables.

\section{Literature Review}

\subsection{Job Characteristic}

Lussier and Hendon (2016) stated that job characteristic is to provide a conceptual framework for designing or enriching jobs enriching jobs based on core job characteristics. The model can be used by individual managers or by members of a team. Use of the job characteristics model improves employees' motivation and job satisfaction, and it can increase performance. The use of job characteristics is to improve employees' motivation, performance, and job satisfaction and reduces their absenteeism and turnover.

According to Robbins and Judge (2015) that increasingly, research on motivation focuses on approaches that link motivational concepts to changes in the way work is structured. Research in job design suggests the way the elements in a job are organized can increase or decrease effort and also suggests what those elements are. First, will review the job characteristics model and then discuss some ways of jobs can be redesigned. Finally, exploring alternative work arrangements.

Developed by J. Richard Hackman and Greg Oldham, the job characteristics model can describe any job in terms of five core job dimensions:

- Skill Variety - the degree to which a job requires variety of different activities so the worker can use specialized skills and talents.

- Task Identity - the degree to which a job requires completion of a whole and identifiable piece of work.

- $\quad$ Task significance - is the degree to which a job affects the lives of work of other people.

- Job Autonomy - the degree to which a job provides the worker freedom, independence, and discretion in scheduling work and determining the procedures for carrying it out.

- Job feedback - the degree to which carrying out work activities generates direct and clear information about your own performance.

\subsection{Career Development}

According to Zarqan (2017) that career development as an effort or steps which was implemented by the company or the manager of human resources in order to frame the development of employees' potential to be able to handle certain task in a higher positions in the effort of achieving the company's objective.

Lussier and Hendon (2016) stated that career development become a significant issue to companies, and what problems does career planning need to be designed to solve. Today's organizations need to provide employees with reasonable career paths and career counseling so that they achieve their personal goals over the course of their career. These services can create significant motivation in the workforce that can lead to a major improvement in productivity and job satisfaction as well as lower absenteeism and turnover.

The process of increasing individual's working skills can be achieved by a desired career. There are several issues in the career development process in a company, as one of them is the object of research, such as lacking of promotion career paths, the employees remain in the same position for a certain period of time. Most of the employees will want to have a higher position and facility in a company, especially for those employees who have been working for a long period of time in the company. According to Handoko (2014) that the dimensions and indicators of career development are explained below:

- Education - Educational background and knowledge insights.

- Training - Frequency of training and certain working skills.

- Work Experience - Length of work, mastery of knowledge and skills.

\subsection{Organizational Commitment}

According to Arijanto, Permana, Mighty, and Soelton (2018) that organizational commitment is a condition where an employee in a particular organization, have intention and desire to maintain their membership and engagement in the organization. And according to Robbins and Judge (2015) that organizational commitment is defined as a high job involvement and taking sides on a particular work of an individual, while the high organizational commitment means that taking sides with the organization who recruits the individual who will remain in the organization.

Colquitt, Lepine, and Wesson (2017) explain that organizational commitment can be interpreted as the desire of employees to remain member of an organization. Organizational commitment can influence whether an employee will remain as a member of the organization (maintained) or go to pursue another job (employee exchange). Employees who are not committed to their organization are involved in withdrawal behavior, defined as a series of actions taken by the employee to avoid situations-work behavior that may eventually lead to resignation from the organization. 
Colquitt et al express that organizational commitment has three basic dimension that are closely related as follows:

- Affective Commitment - a desire to remain a member of an organization because of its emotional attachment and involvement with the organization.

- Normative Commitment - a desire to remain a member of an organization because of awareness of the costs associated with leaving the organization.

- Continuance Commitment - a desire to remain a member of an organization because of the feeling of having an obligation to remain with the organization.

\subsection{Turnover Intention}

According to Lussier and Hendon (2016) that turnover is the permanent loss of workers from the organization. What specific issues are associated with turnover? Well, first is the cost of the paperwork associated with the departing employees, and if they left involuntarily, we may have increases in our unemployment insurance payments and might even have some potential security issues. Next, there is finding someone else to do the job, which incurs job analysis costs, recruiting cost, and selection costs. Once we hire someone new, we have orientation and other training costs, costs associated with getting the new worker up to speed on their job and the costs associated with them just not knowing our way of doing business. So again, because there are so many costs associated with turnover in the organization, the turnover must be minimized.

Arshad and Puteh (2015) stated that turnover is the flow of employees entering and leaving the company. According to Belete (2018) turnover intention can be influenced by work stress, organizational commitment and job satisfaction. High employees' turnover is a measure that is often used as an indication of an underlying issue in an organization (Song, 2016).

According to Yamazakia and Petchdee (2015) that a low turnover intention can reduce the employees' turnover and reduce costs in a company. The definition of turnover according to some of the experts can be concluded that turnover intention is the desire of the employees to leave or move out of the company arising from their own desires or due to the termination of relationship from the company.

According to Mobley (1977) that there are two dimensions that are closely related to turnover intention mentioned as follows:

- External Factors - higher salary, self-potential development and better offer.

- Internal Factors - working environment, worker's relationship, compensation, work load.

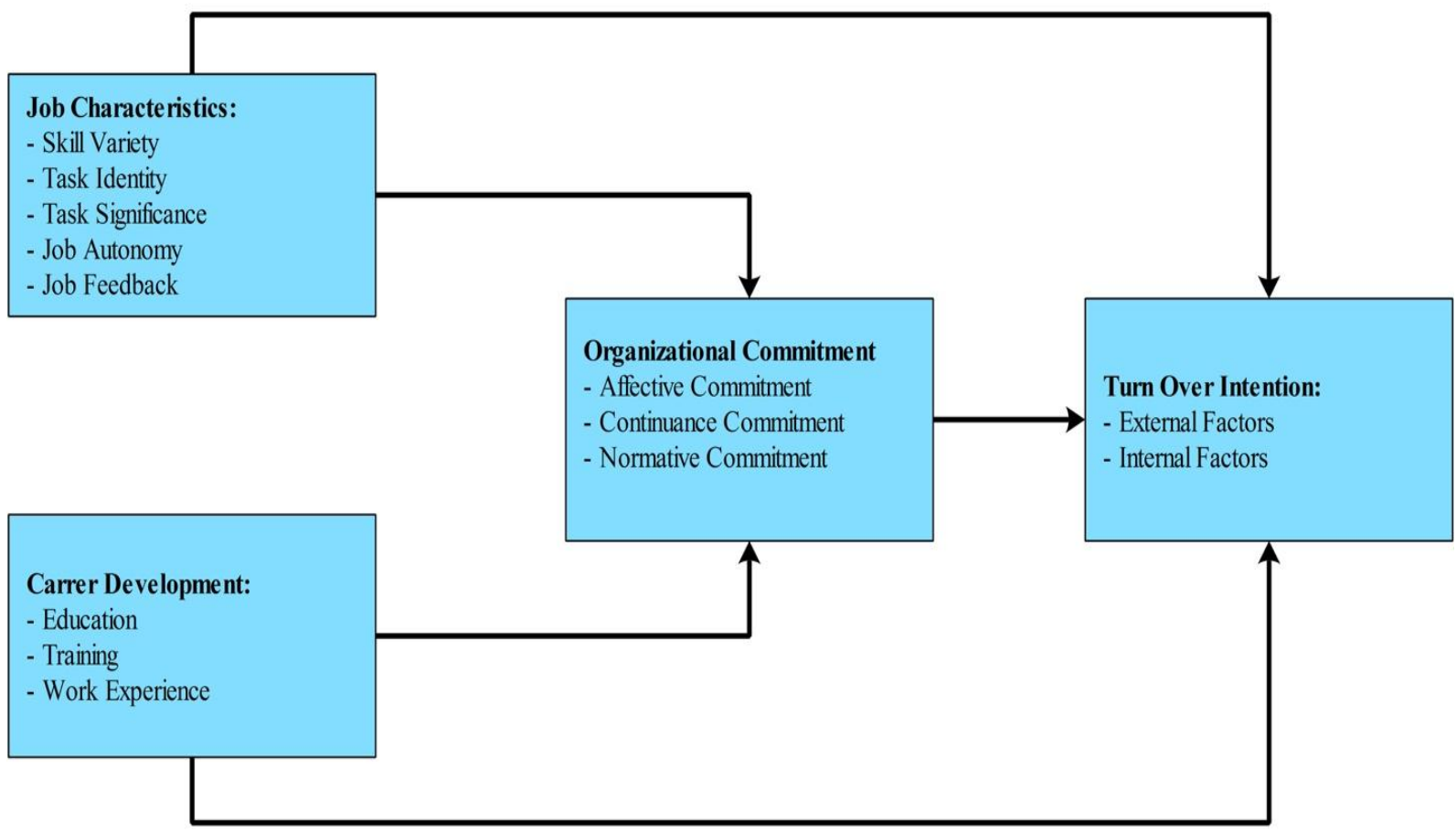

Figure-1. Research paradigm.

\section{Methodology}

The design of this research is using human resource management approach that include the operational variables, data collection method and information collection, defining the population, 
calculating the sample size and sampling techniques. This research begins with the preliminary research and follows by formulating the construct variables.

The formulation and purpose of this study is to describe and reveal the interrelationship between the research variables explained above. This research is using descriptive and verification method with the type of causal research on the relationship and influence between the exogenous and endogenous variables.

The process of observation in this research is using time horizon with cross section/one shot, the collective data is obtained from the research done in 2019, the unit of analysis are the employee of the IT provider products and services company in Jakarta, Indonesia. The design of analysis is using Partial Least Square (PLS) as the alternative method from Structural Equation Modeling (SEM).

The validity testing was done by using the sample of 187 respondents randomly on the IT provider company. The attempt of this validity testing is to find out the eligible of the selected items including the overall data collection process. The results of the validity test are as follows:

Table-1. Validity test results.

\begin{tabular}{|c|c|c|c|c|}
\hline Variable & Dimension & Item & Correlation & Description \\
\hline \multirow{10}{*}{ Job characteristics } & \multirow{2}{*}{ Skill variety } & $\mathrm{X} 11$ & 0.535 & Valid \\
\hline & & $\mathrm{X} 12$ & 0.524 & Valid \\
\hline & \multirow{2}{*}{ Task identity } & $\mathrm{X} 21$ & 0.540 & Valid \\
\hline & & $\mathrm{X} 22$ & 0.575 & Valid \\
\hline & \multirow{2}{*}{ Task significance } & $\mathrm{X} 31$ & 0.683 & Valid \\
\hline & & $\mathrm{X} 32$ & 0.624 & Valid \\
\hline & \multirow{2}{*}{ Job autonomy } & $\mathrm{X} 41$ & 0.727 & Valid \\
\hline & & $\mathrm{X} 42$ & 0.676 & Valid \\
\hline & \multirow{2}{*}{ Job feedback } & $\mathrm{X} 51$ & 0.673 & Valid \\
\hline & & $\mathrm{X} 52$ & 0.725 & Valid \\
\hline \multirow{6}{*}{ Career development } & \multirow{2}{*}{ Education } & $\mathrm{X} 61$ & 0.765 & Valid \\
\hline & & $\mathrm{X} 62$ & 0.505 & Valid \\
\hline & \multirow{2}{*}{ Training } & $\mathrm{X} 71$ & 0.735 & Valid \\
\hline & & $\mathrm{X} 72$ & 0.625 & Valid \\
\hline & \multirow{2}{*}{ Work experience } & $\mathrm{X} 81$ & 0.712 & Valid \\
\hline & & $\mathrm{X} 82$ & 0.658 & Valid \\
\hline \multirow{12}{*}{ Organizational commitment } & \multirow{3}{*}{ Affective } & Y11 & 0.592 & Valid \\
\hline & & Y12 & 0.717 & Valid \\
\hline & & Y13 & 0.687 & Valid \\
\hline & \multirow{3}{*}{ Continuance } & $\mathrm{Y}_{21}$ & 0.683 & Valid \\
\hline & & Y22 & 0.559 & Valid \\
\hline & & Y23 & 0.560 & Valid \\
\hline & \multirow{3}{*}{ Normative } & Y31 & 0.594 & Valid \\
\hline & & Y32 & 0.701 & Valid \\
\hline & & Y33 & 0.697 & Valid \\
\hline & \multirow{3}{*}{ External factors } & $\mathrm{Z}_{11}$ & 0.829 & Valid \\
\hline & & $\mathrm{Z}_{12}$ & 0.867 & Valid \\
\hline & & Z13 & 0.728 & Valid \\
\hline \multirow{3}{*}{ Turnover intention } & \multirow{3}{*}{ Internal factors } & Z21 & 0.652 & Valid \\
\hline & & Z22 & 0.736 & Valid \\
\hline & & Z23 & 0.777 & Valid \\
\hline
\end{tabular}

Based on Table 1, the calculation of the item score correlation with the total score show that the validity coefficient is greater than 0.300 , so all the items used to measure the said variables are considered as valid.

The reliability test of this research data is using Cronbach's alpha coefficient method. The Cronbach's alpha coefficient is the reliability coefficient that are most commonly used because the coefficient will indicate the variance of items with either correct or incorrect format such as Likert scale format. 
The criteria of determining a valid item and having a reliable value that can be accepted are based on the table described Table 2 .

Table-2. Standard criteria of validity and reliability research.

\begin{tabular}{c|c|c}
\hline Description & Reliability & Validity \\
\hline Good & 0.8 & 0.5 \\
\hline Acceptable & 0.7 & 0.3 \\
\hline Marginal & 0.6 & 0.2 \\
\hline Poor & 0.5 & 0.1 \\
\hline Source: Barker, Pistrang, and Elliott $(2002)$.
\end{tabular}

Table-3. Reliable test result.

\begin{tabular}{c|c|c}
\hline Variable & Cronbach's alpha & Description \\
\hline Job characteristics & 0,740 & Reliable \\
\hline Career development & 0,780 & Reliable \\
\hline Organizational commitment & 0,764 & Reliable \\
\hline Turnover intention & 0,858 & Reliable \\
\hline
\end{tabular}

The result of the above calculation of the score items with the total based on the Table 3 has a reliability coefficient Cronbach alpha's value which is greater 0,7 which means that all instruments can be classified as reliable.

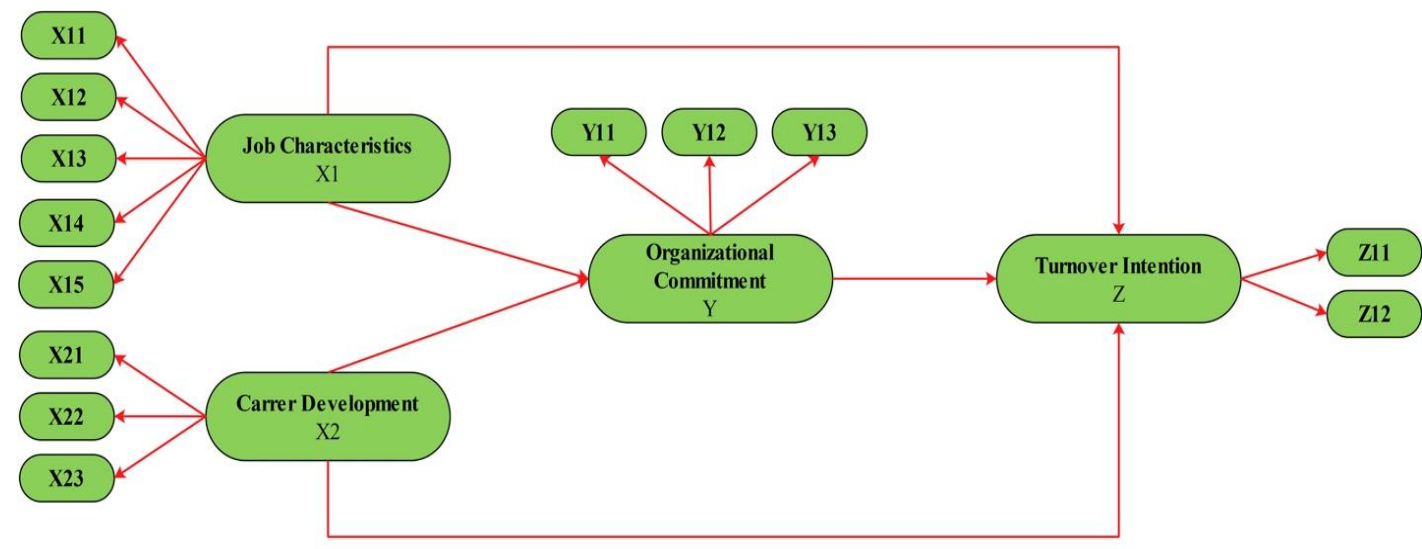

Source: From data processing (2019)

Figure-2. The correlation of variables.

\section{Result and Discussion}

The measurement model of analysis above shows the link between manifest variables (indicators) and each of the latent variables. The analysis of the measurement model is to test the validity and reliability of each of the dimensions and the indicators utilized to measure the variables constructed earlier. The analysis of the measurement model describe that the value of discriminant validity is by looking at the value of square root of Average Variance Extracted (AVE) with the suggestion value above 0,5, loading factor $(>0.5)$, and constructed Composite Validity and Reliability (Cronbach's Alpha $>0.70$ ). Therefore, the conclusion of the dimensions and indicators which are classified as reliable earlier are showed Table 4:

\begin{tabular}{l|c|c|c|c}
\multicolumn{7}{c}{ Table-4. Goodness of fit model (GoF). } \\
\hline Variable & AVE & Composite reliability & Cronbach's alpha & R Square \\
\hline Career development & 0.546 & 0.756 & 0.740 & - \\
\hline Job characteristics & 0.528 & 0.828 & 0.780 & - \\
\hline Organizational commitment & 0.558 & 0.846 & 0.801 & 0.538 \\
\hline Turnover intention & 0.590 & 0.895 & 0.858 & 0.729 \\
\hline
\end{tabular}

Source: Form data processing (2019).

Predictive relevance value is obtained by the formula:

$$
\begin{aligned}
& Q^{2}=1-(1-R 1)\left(1-R_{p}\right) \\
& Q^{2}=1-(1-0.538)(1-0.729) \\
& Q^{2}=1-(0.462)(0.271)
\end{aligned}
$$


$Q^{2}=0.8748$

From the above Goodness of Fit table, it pointed out that the value of $\mathrm{R} 2$ shows that the criteria are strong, with a large $Q$ value, it can be concluded that the proposed model is supported by empirical research which is quite suitable. Likewise, the AVE values are $>0.5$, indicating that all variables in the model are estimated to meet the discriminant validity criteria. The value of Composite Reliability and Cronbach's alpha for each variable is $>0.70$ (above 0.70 ) meaning that all variables studied are classified as reliable.

Table-5. Hypothesis testing results.

\begin{tabular}{|c|c|c|c|c|c|}
\hline & $\begin{array}{c}\text { Original } \\
\text { sample }\end{array}$ & $\begin{array}{l}\text { Standard } \\
\text { deviation }\end{array}$ & $\begin{array}{c}\mathrm{T}- \\
\text { Statistics }\end{array}$ & $\begin{array}{c}\mathbf{P} \\
\text { values }\end{array}$ & Conclusion \\
\hline $\begin{array}{l}\text { Job characteristics } \rightarrow \\
\text { Organizational commitment }\end{array}$ & 0.187 & 0.073 & 2.584 & 0.01 & Positive - Significant \\
\hline $\begin{array}{l}\text { Career development } \rightarrow \\
\text { Organizational commitment }\end{array}$ & 0.105 & 0.073 & 1.426 & 0.154 & Not Significant \\
\hline $\begin{array}{l}\text { Job characteristics } \rightarrow \text { Turnover } \\
\text { intention }\end{array}$ & -0.145 & 0.065 & 2.222 & 0.027 & Negative - Significant \\
\hline $\begin{array}{l}\text { Career development } \rightarrow \text { Turnover } \\
\text { intention }\end{array}$ & -0.217 & 0.075 & 2.225 & 0.004 & Negative - Significant \\
\hline $\begin{array}{l}\text { Organizational commitment } \\
\rightarrow \text { Turnover intention }\end{array}$ & -0.689 & 0.058 & 4.795 & $\mathrm{O}$ & Negative - Significant \\
\hline
\end{tabular}

Source: Form data processing (2019)

From the results of hypothesis testing, it was revealed that job characteristics has the greater influence on organizational commitment compared to career development. While organizational commitment is an important factor in determining the turnover intention of the millennial workforce.

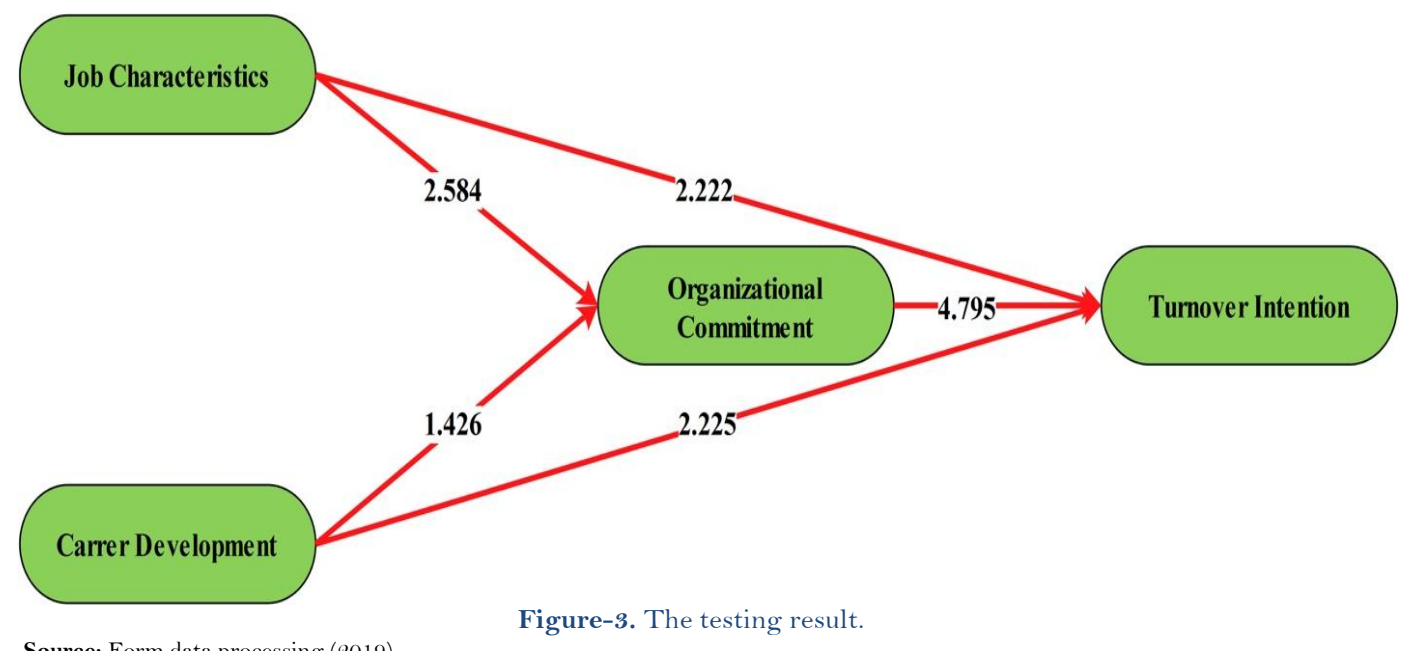

Source: Form data processing (2019).

Based on the testing result above, the research variables indicated that job characteristics has the most significant influence on organizational commitment as the intervening variable, which is 2.584 compare to the variable of career development which is 1.426 . The direct effect job characteristics contributed lower influence towards turnover intention with the figure of 2.222 compare to career development with the figure of 2.225. Organizational commitment has a direct effect against turnover intention with the figure of 4.795.

\section{Conclusion and Recommendation}

\subsection{Conclusion}

The result of the hypothesis testing concluded that a proper development of job characteristics is very important and make a significant difference in the working environment and obtain the organizational commitment of the workforce and prevent them from taking the action of leaving the company to seek better offer of job outside the company.

The objectives of this research are to find out the basic issues encounter by the company of IT provider and products concerning the turnover intention of the employees in Jakarta, Indonesia. This research has constructed that five research variables in order to find out the main cause of the problem. The result of the hypothesis testing concludes several findings as follows: 
1. The performance of the employees in the IT provider company has not met the target of the company due to the lack of ability, basic education, expertise, skills and working experience. Based on these issues the employees are sometimes frustrated and the eagerness and intention to leave the company increase.

2. The company does not provide a clear and job description and succession planning for the employees based on their skills and capabilities. Thus, the qualified employees also losing hope and the intention to seek better opportunities outside increase.

3. No specific motivation of compensation given to the certain achievements reached by the capable and skillful employees, to motivate them to reach certain target with clear compensation. Such as bonus, incentives and rewards based on their achievements. Hence, the employees feel of no proper compensation to achieve.

4. The company also pays less attention of the performance and discipline of the employees, which caused the absenteeism of the employee, and no further reward and punishment given to the lack discipline employees.

The result of this research is to bring into attention that this phenomenon that may also occured in the rest of the country. It would be worthwhile to study and further development of proper job characteristics to suit the millennial workforce to increase the company performance.

\section{Recommendation}

Based on the conclusion above, the results of this study has pointed out that the organization today must pay more attention and understand the millennial workforce because they are somehow very different from the previous generation, and in order to achieve long-term success, the organization must meet the challenge of managing a diverse characters of the millennial workforce.

It is crucial to understand how to motivate this millennials and develop a clear HR system for reward and punishment to discipline the employees and also giving motivation to develop their way of thinking to perform their tasks.

There is also a need of proper training skills for the employees to prevent them from making mistakes and perform a better quality of performance.

The organizations may take this research as a guidance to proceed with further study to understand the millennial workforce and turnover intention and how to motivate them to provide better improvement in the organizations.

\section{References}

Arijanto, A., Permana, D., Mighty, D., \& Soelton, M. (2018). Organizational behavior: Theory, process, and implementation for students, academics and practitioners to face the Era of the Industrial revolution 4.0. Jakarta: Moeka Publishing Page.

Arshad, H., \& Puteh, F. (2015). Determinants of turnover intention among employees. Journal of Administrative Science, $12(2), 1-15$.

Barker, N., Pistrang, N., \& Elliott, R. (2002). Foundations of qualitative methods. Research Methods in Clinical Psychology: An Introduction for Students and Practitioners, 5-72.

Belete, A. (2018). Turnover intention influencing factors of employees: An empirical work review. Journal of Entrepreneurship \& Organization Management, 7(253), 2.

Colquitt, A. J., Lepine, A. J., \& Wesson, J. M. (2017). Organizational behavior (5th ed.). New York, USA: McGraw-Hill Education.

Emiroglu, B. D., Akova, O., \& Tanriverdi, H. (2015). The relationship between turnover intention and demographic factors in hotel business: A study at five stars hotels in Istanbul. Procedia-Social and Behavioral Sciences, 207, 385-397.

Gadi, D. P., \& Hung, D. M. D. (2018). Human resource management practices and turnover intention: The mediating role of perceived organizational support in tertiary institutions in Nigeria. International Journal of Engineering $\mathcal{E}^{\circ}$ Technology.

Handoko, T. H. (2014). Personnel and human resource management. Yogyakarta: Penerbit BPFE.

Harzing, A.-W., \& Pennington, A. H. (2015). International human resource management (4th ed.). London: Sage Publication Ltd.

Long, C. S., \& Perumal, P. (2014). Examining the impact of human resource management practices on employees' turnover intention. International Journal of Business and Society, 15(1), 111-126.

Lussier, R. N., \& Hendon, J. R. (2016). Human resource management. Functions, applications, \& skill development (2nd ed.). California, USA: Sage Publication Inc.

Mobley, W. H. (1977). Intermediate linkages in the relationship between job satisfaction and employee turnover. Journal of Applied Psychology, 62(2), 237-240. Available at: https://doi.org/10.1037//002 1-90 10.62.2.237.

Nasurdin, A. M., Ling, T. C., \& Khan, S. N. (2018). The relation between turnover intention, high performance work practices, and organizational commitment: A study among private hospital nurses in Malaysia. Asian Academy of Management Journal, 23(1).

Noe, R. A., Hollenbeck, J. R., Gerhart, B., \& Wright, P. M. (2017). Human resource management: Gaining a competitive advantage (1 oth ed.). New York, USA: McGraw-Hill Education.

Ramli, Y., \& Soelton, M. (2019). The millennial workforce: How do they commit to the organization? International Journal of Business, Economics and Law, 19(5), 7-18.

Robbins, S. R., \& Judge, T., A. (2015). Organizational behavior (6th ed.). England: Pearson Education Limited. 
Song, L. (2016). A study of factors influencing turnover Intention of King Power group at downtown area in Bangkok, Thailand. International Review of Research in Emerging Markets and the Global Economy, 2(3), 895-908.

Yamazakia, Y., \& Petchdee, S. (2015). Turnover intention, organizational commitment, and specific job satisfaction among production employees in Thailand. Journal of Business and Management, 4(4), 22-38. Available at: https://doi.org/10.12735/jbm.v4i4p22.

Zahra, S. S., Khan, M. I., Aman, Q., \& Ali, R. (2018). The relationship between job stress and turnover intentions in the Pesticide Sector of Pakistan: An employee behavior perspective. Management Issues in Healthcare System, 4, 1-12.

Zarqan, I. A. (2017). Human resource development in the Era of technology; Technology's implementation for innovative human hesource development. Jurnal Manajemen Teori dan Terapan| Journal of Theory and Applied Management, 10(3), 217-223. Available at: https://doi.org/10.20473/jmtt.v10i3.5967. 